\title{
Cultural Guidelines for Commercial Production of Interiorscape Hedera ${ }^{1}$
}

\author{
Jianjun Chen, Dennis B. McConnell, and Kelly C. Everitt ${ }^{2}$
}

\section{Introduction}

The genus Hedera belongs to the family Araliaceae and comprises about 11 species. Among them, H. helix, commonly known as English ivy, is native to temperate regions of Europe, northern Africa, and western Asia and is probably the most significant species used worldwide as a foliage plant. It is commonly grown as a potted or hanging basket plant and can be used effectively in dish gardens and other combination planters. In large interior plantscapes, English Ivy makes a good ground cover or it can be trained into formal shapes on trellises or made into topiary figures.

Two noticeable characteristics of English Ivy are its evergreen leaves and the fact that it develops both juvenile and adult foliage. Juvenile leaves, usually three- to five-lobed, are produced on flexible stems that may form roots on every node while growing as a ground cover or a climbing vine. Adult leaves are produced on stiff, nonclimbing and rootless stems and are elliptic-lanceolate and not lobed. After adult foliage appears, flowers may develop in globose umbels, usually in compound panicles, with each umbel carrying 10-15 flowers.

According to the American Ivy Society (Naples, FL), ivy leaf shapes can be classified into nine categories in reference to the Pierot System: variegated $(\mathrm{V})$, birds foot $(\mathrm{BF})$, fan $(\mathrm{F})$, curlies $(\mathrm{C})$, heart-shapes $(\mathrm{H})$, miniature $(\mathrm{M})$, ivy-ivies (I), adult (A), and oddities (O) (www.ivy.org). Plants with different leaf shapes and variegation patterns, if stable in propagation, could potentially become new cultivars. The American Ivy Society is the International Registration Authority for new ivy cultivar registration. There are more than 200 cultivars of $H$. helix varying in leaf sizes, shapes, colors, and variegation patterns; all were selected from sports.

English Ivy is capable of adapting to a wide range of environmental conditions; it has been listed as an invasive plant in many states but not Florida. This article is intended to describe common species and cultivars grown in the foliage plant industry, provide guidelines for their culture and interior use, and list physiological problems that may be

1. This document is ENH 990, one of a series of the Environmental Horticulture Department, Florida Cooperative Extension Service, Institute of Food and Agricultural Sciences, University of Florida. Original publication date November 4, 2004. Revised May, 2005. Visit the EDIS Web Site at http://edis.ifas.ufl.edu.

2. Jianjun Chen, Associate Professor, Mid-Florida Research and Education Center and Environmental Horticultural Department, Dennis B. McConnell, Professor, Environmental Horticultural Department, and Kelly C. Everitt, Research Assistant, Mid-Florida Research and Education Center at the Institute of Food and Agricultural Sciences, University of Florida.

The Institute of Food and Agricultural Sciences (IFAS) is an Equal Employment Opportunity - Affirmative Action Employer authorized to provide research, educational information and other services only to individuals and institutions that function without regard to race, creed, color, religion, age, disability, sex, sexual orientation, marital status, national origin, political opinions or affiliations. For information on obtaining other extension publications, contact your county Cooperative Extension Service office. Florida Cooperative Extension Service / Institute of Food and Agricultural Sciences / University of Florida / Larry R. Arrington, Interim Dean 
encountered during production and interiorscape use. It is suggested that the potential invasiveness of this species be noted at the retail level and that buyers be advised to only use this plant where it cannot become a nuisance.

\section{Species and Cultivars}

See Table 1.

\section{Cultural Guides}

\section{Propagation}

Juvenile English ivy is propagated by cuttings; tissue culture is not currently used commercially. Both tip and nodal cuttings root readily with single node cuttings more commonly used commercially than double node cuttings. Cuttings are rooted singly in cell plugs but multiply in 4-, 6-, or 8 -inch pots. The rooting media can be formulated by using 40 to $60 \%$ Canadian peat combined with an equal volume of perlite and vermiculate. Media should have good water-holding capacity and aeration, with soluble salts between $1-3 \mathrm{dS} / \mathrm{m}$ and a $\mathrm{pH}$ of 5.5 to 6.5 . Cuttings root best under mist in a shaded greenhouse or shadehouse under a light level of 1000-1500 fc and temperatures between 70 to $86^{\circ} \mathrm{F}$.

\section{Production}

The best quality English ivy is produced if temperatures are between 70 and $90^{\circ} \mathrm{F}$ and the relative humidity is between 60 and $100 \%$. Plant quality and growth rates begin to decline when day temperatures routinely exceed $95^{\circ} \mathrm{F}$ or night temperatures drop below $65^{\circ} \mathrm{F}$. Controlled-release or water-soluble fertilizers, or a combination of both, can be used for ivy production. A fertilizer with $\mathrm{N}-\mathrm{P}_{2} \mathrm{O}_{5}-\mathrm{K}_{2} \mathrm{O}$ ratio at 3-1-2 or 2-1-2 should be used at the rate of 25 pounds of $\mathrm{N}$ per 1,000 square feet annually. Table 2 provides a guide for determining if English Ivy is appropriately fertilized based on leaf analysis. Light intensity should range from 1500 to $2500 \mathrm{fc}$. The media should dry slightly before re-irrigating as plants grow poorly if the media is kept extremely wet or dry. Xanthomonas leaf spot disease may occur if overhead irrigation is used.
See Table 2.

\section{Shipping and Interior Care}

Use protective sleeves when shipping finished $H$. helix. High quality plants will be retained if shipping temperatures can be kept between 50 and $60^{\circ} \mathrm{F}$. Once plants are placed indoors, it is advisable not to re-pot or fertilize them for about four weeks. This allows the plant to recover from any shipping stress. Plants should not be fertilized if soluble salts are 2.0 $\mathrm{dS} / \mathrm{m}$ or more. If soluble salt levels are higher than $3.0 \mathrm{dS} / \mathrm{m}$, leaching the media with water may help reduce potential leaf necrosis or damage to the root system. Keep the media moist during the first two to three weeks indoors, and then water less frequently. Whether plants are in hanging baskets or free-standing pots, English Ivy will retain its aesthetic appearance under light levels as low as $100 \mathrm{fc}$ if temperatures are kept between 70 and $80^{\circ} \mathrm{F}$. Pinch any long stems to promote a bushy growth habit. Overcrowded plants can repotted at any time of the year.

\section{Physiological Problems}

See Table 3. 
Table 1. A listing of most of the cultivars available in Florida as of 2004.

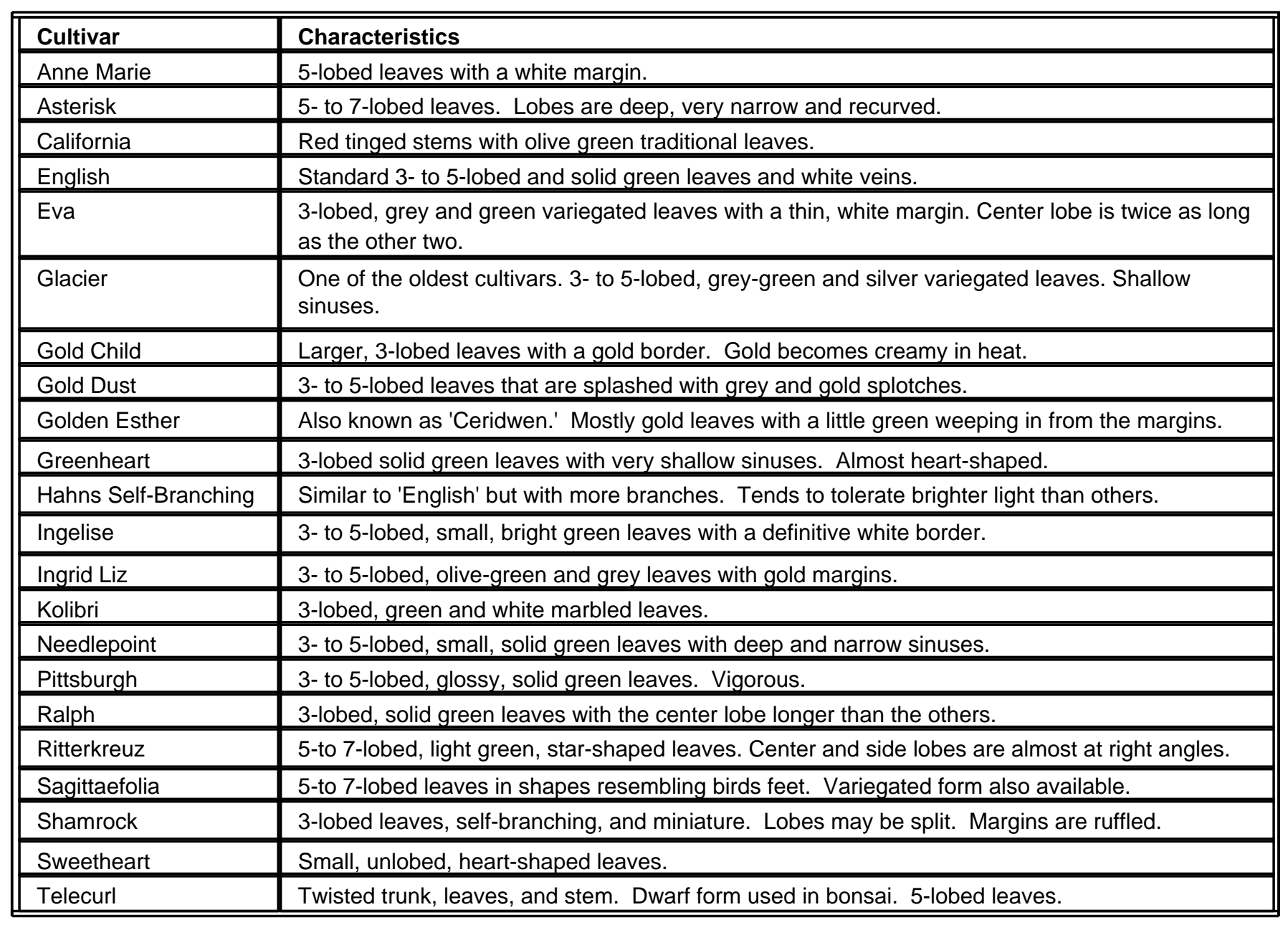

Table 2. Nutrient concentrations in leaves considered low, medium, and high for Hedera growth.

\begin{tabular}{||l|l|l|l||}
\hline \hline Nutrient & Low & Medium & High \\
\hline Nitrogen & less than $2.5 \%$ & $2.5-4.5 \%$ & greater than $4.5 \%$ \\
\hline Phosphorus & less than $0.3 \%$ & $0.3-0.9 \%$ & greater than $0.9 \%$ \\
\hline Potassium & less than $1.5 \%$ & $1.5-4.5 \%$ & greater than $4.5 \%$ \\
\hline Calcium & less than $1.0 \%$ & $1.0-2.0 \%$ & greater than $2.0 \%$ \\
\hline Magnesium & less than $0.3 \%$ & $0.3-0.7 \%$ & greater than 0.7 \% \\
\hline Sulfur & less than $0.3 \%$ & $0.3-0.5 \%$ & greater than $0.5 \%$ \\
\hline Iron & less than $50 \mathrm{ppm}$ & $50-350 \mathrm{ppm}$ & greater than $350 \mathrm{ppm}$ \\
\hline Manganese & less than $50 \mathrm{ppm}$ & $50-200 \mathrm{ppm}$ & greater than $200 \mathrm{ppm}$ \\
\hline Zinc & less than $20 \mathrm{ppm}$ & $20-100 \mathrm{ppm}$ & greater than $100 \mathrm{ppm}$ \\
\hline Copper & less than $5 \mathrm{ppm}$ & $5-25 \mathrm{ppm}$ & greater than $25 \mathrm{ppm}$ \\
\hline Boron & less than $20 \mathrm{ppm}$ & $20-50 \mathrm{ppm}$ & greater than $50 \mathrm{ppm}$ \\
\hline \hline
\end{tabular}


Table 3. Causes and effects of various physiological problems.

\begin{tabular}{|c|c|c|}
\hline Symptoms & Probable Cause & Treatment \\
\hline Thin, spindly growth. & $\begin{array}{l}\text { Too little light with too much water } \\
\text { and fertilizer. }\end{array}$ & $\begin{array}{l}\text { Reduce water and fertilizer or move to a brighter } \\
\text { location. }\end{array}$ \\
\hline Leaf burn. & High soluble salts in potting media. & $\begin{array}{l}\text { Use the pour-through method to check media } \\
\text { soluble salts and maintain soluble salt levels } \\
\text { between } 1.0 \text { to } 3.0 \mathrm{dS} / \mathrm{m} \text {. }\end{array}$ \\
\hline $\begin{array}{l}\text { Small yellow spots on } \\
\text { the surface of leaves. }\end{array}$ & $\begin{array}{l}\text { Edema occurs when more water is } \\
\text { taken up by the roots than can be } \\
\text { given off by the leaves. Certain leaf } \\
\text { cells become engorged with and } \\
\text { water and swell. }\end{array}$ & $\begin{array}{l}\text { Increase the temperature and ventilation around the } \\
\text { plant to facilitate moisture loss through the leaves. } \\
\text { Over-watered plants are highly susceptible to } \\
\text { edema. }\end{array}$ \\
\hline $\begin{array}{l}\text { Loss of variegation in } \\
\text { young leaves. }\end{array}$ & Very low light. & Move plant to brighter conditions. \\
\hline $\begin{array}{l}\text { Loss of variegation in } \\
\text { older leaves. }\end{array}$ & Age, low light. & None, although brighter conditions may help. \\
\hline $\begin{array}{l}\text { Change in leaf } \\
\text { shape/color. }\end{array}$ & Unstable cultivar. & Prune unwanted growth. \\
\hline $\begin{array}{l}\text { Slow growth and/or } \\
\text { rooting. }\end{array}$ & High temperatures. & $\begin{array}{l}\text { Lower temperatures and increase ventilation. } \\
\text { Common in the south during summer. }\end{array}$ \\
\hline Brown leaf edges. & High heat; spider mites. & $\begin{array}{l}\text { Move to an area where temperatures are no higher } \\
\text { than } 85^{\circ} \mathrm{F} \text { and increase the humidity. If spider } \\
\text { mites are detected, wash leaves in } 1 \% \text { soap and } \\
\text { water solution. Remove damaged leaves. }\end{array}$ \\
\hline
\end{tabular}

